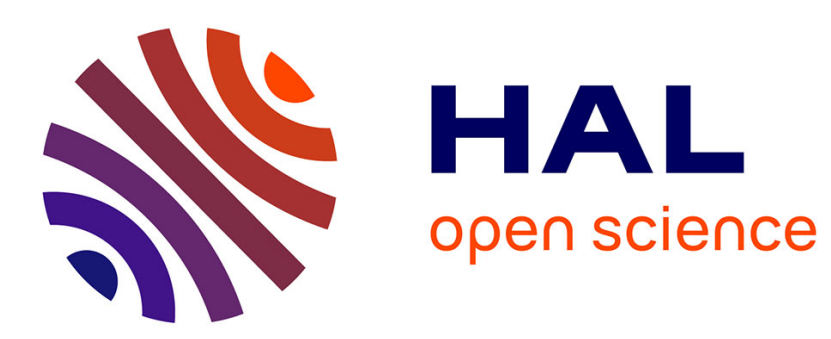

\title{
On the difficulties of being rigorous in environmental geochemistry studies: some recommendations for designing an impactful paper
}

\author{
Olivier Pourret, Jean-Claude Bollinger, Eric D. van Hullebusch
}

\section{To cite this version:}

Olivier Pourret, Jean-Claude Bollinger, Eric D. van Hullebusch. On the difficulties of being rigorous in environmental geochemistry studies: some recommendations for designing an impactful paper. Environmental Science and Pollution Research, 2020, 27, pp.1267-1275. 10.1007/s11356-019-06835y . hal-02365449

\author{
HAL Id: hal-02365449 \\ https://hal.science/hal-02365449
}

Submitted on 15 Nov 2019

HAL is a multi-disciplinary open access archive for the deposit and dissemination of scientific research documents, whether they are published or not. The documents may come from teaching and research institutions in France or abroad, or from public or private research centers.
L'archive ouverte pluridisciplinaire HAL, est destinée au dépôt et à la diffusion de documents scientifiques de niveau recherche, publiés ou non, émanant des établissements d'enseignement et de recherche français ou étrangers, des laboratoires publics ou privés. 


\section{Trend Editorial}

On the difficulties of being rigorous in environmental geochemistry studies: some recommendations for designing an impactful paper

Olivier Pourret ${ }^{1, *}$, Jean-Claude Bollinger ${ }^{2}$, Eric D. van Hullebusch ${ }^{3,4}$

${ }^{1}$ UniLaSalle, AGHYLE, 19 rue Pierre Waguet, 60026 Beauvais cedex, France

${ }^{2}$ Université de Limoges, PEREINE, Faculté des Sciences et Techniques, 123 avenue AlbertThomas, 87060 Limoges, France

${ }^{3}$ IHE Delft, Institute for Water Education, Westvest 7, 2611 AX Delft, The Netherlands

${ }^{4}$ Université de Paris, Institut de physique du globe de Paris, CNRS, F-75005 Paris, France

*Corresponding author

olivier.pourret@unilasalle.fr; +33 244068979 


\begin{abstract}
There have been numerous environmental geochemistry studies using chemical, geological, ecological and toxicological methods but each of these fields requires more subject specialist rigour than has generally been applied so far. Field-specific terminology has been misused and the resulting interpretations rendered inaccurate. In this paper, we propose a series of suggestions, based on our experience as teachers, researchers, reviewers and editorial board members, to help authors to avoid pitfalls. Many scientific inaccuracies continue to be unchecked and are repeatedly republished by the scientific community. These recommendations should help our colleagues and editorial board members, as well as reviewers, to avoid the many inaccuracies and misconceptions currently in circulation and establish a trend towards greater rigour in scientific writing.
\end{abstract}

Keywords: speciation, fractionation, modelling, ecotoxicology, risk assessment, ecology 


\section{Introduction}

In recent times, there has been a notable public loss of trust in scientists, especially in the field of climate change (Trevors and Saier, 2011; Briggs et al., 2011). But why has such a shift in public attitudes towards science taken place, in a time when scientists are expected, more than ever, to conduct their research responsibly and with full rigour?

There are many examples of significant misconduct, such as (among others) the citation of non-contributing authors (Fong and Wilhite, 2017; McNutt et al., 2018; Petersen et al., 2019; Smith et al., 2019; Wilhite et al., 2019; Sweedler, 2019; Chawla, 2019) and the absence of citation that is due (Garfield, 1980; Trevors and Saier, 2008). The general public has become increasingly aware of what constitutes good scientific practice and the performance of scientists is under its scrutiny (Koch, 2016; Goldman et al., 2017; Record, 2017). To resolve this and meet the exacting standards we set ourselves, environmental studies must be irreproachable (Zoller, 2000; Antoniadis et al., 2019; Voulvoulis and Burgman, 2019). Multidisciplinary groups of researchers, that may have different ways of communicating their science, must work together to ensure good practice and well communicated, meaningful results.

Environmental geochemistry is inherently an interdisciplinary academic field. It attempts to explain how life affects, and is affected by, the disturbed biogeochemical cycles of major and trace elements within the Earth critical zone (Amundson et al., 2007; Brantley et al., 2007; Chorover et al., 2007; Field et al., 2015). It studies environmental problems, and how these might be solved (Botkin and Keller, 2014). Environmental geochemistry involves chemistry, physics, climatology, ecology, geology, microbiology, soil science, and toxicology (Ali and Khan, 2017; Filella, 2014; Lichtfouse et al., 2012; Stumm et al., 1983). It can also 
include sociology and economics (Figure 1). It has the power to excite great public strength of feeling (Sedlak, 2016), and is, therefore, subject to heated political debate that sometimes ignores scientific information (Carroll et al., 2017).

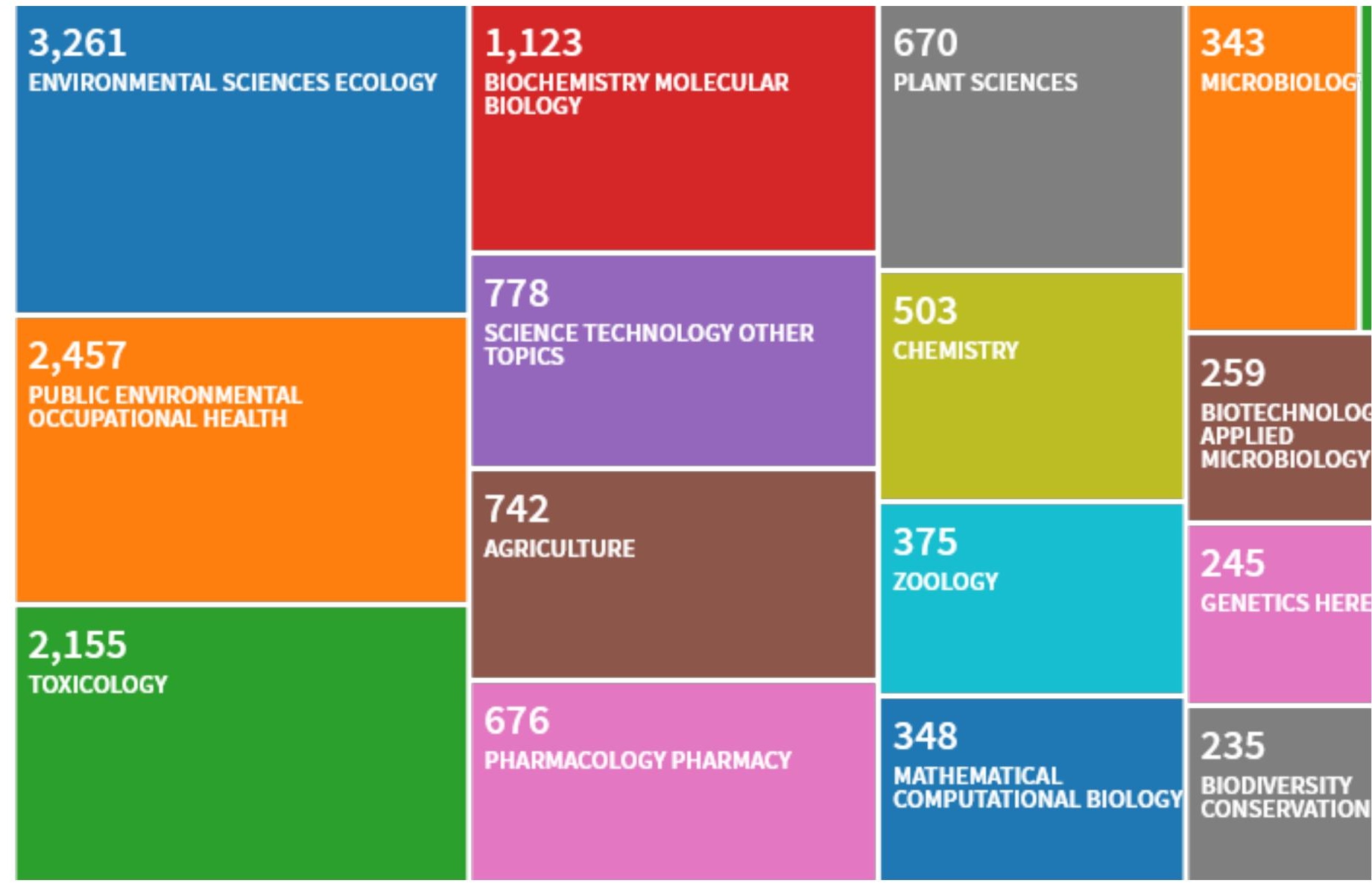

Figure 1 Treemap of the 25 most prevalent field research areas (out of 91) of articles published in 2018 in Environmental Science and Pollution Research (source Web of Science, data accessed on 03/06/2019).

The integration of perspectives from researchers, policy makers, and industrial representatives is essential for successful characterisation and remediation of hazardous anthropogenic contaminations (Sawyer, 1979). Effective interdisciplinary collaboration requires respect for, and a rational balance of, scientific and engineering expertise (Balmford, 
2013). However, several multidisciplinary/interdisciplinary studies (among them papers published in Environmental Science and Pollution Research) used chemical, geological, ecological or toxicological methods (Figure 2), but not as rigorously as specialist researchers would in each of the separate fields. Indeed, the field-specific terminology is often loosely adopted and imprecise, which leads to equally imprecise interpretation of the results (Casadevall and Fang, 2016; Hofseth, 2018). Scientists need to use technical language. Without it, environmental geochemistry would not exist as a discipline. It is the responsibility of scientists to select the correct tone and technical content, and to make sure that jargon (unnecessary and extraneous use of technical terms) is not used when communicating with others.

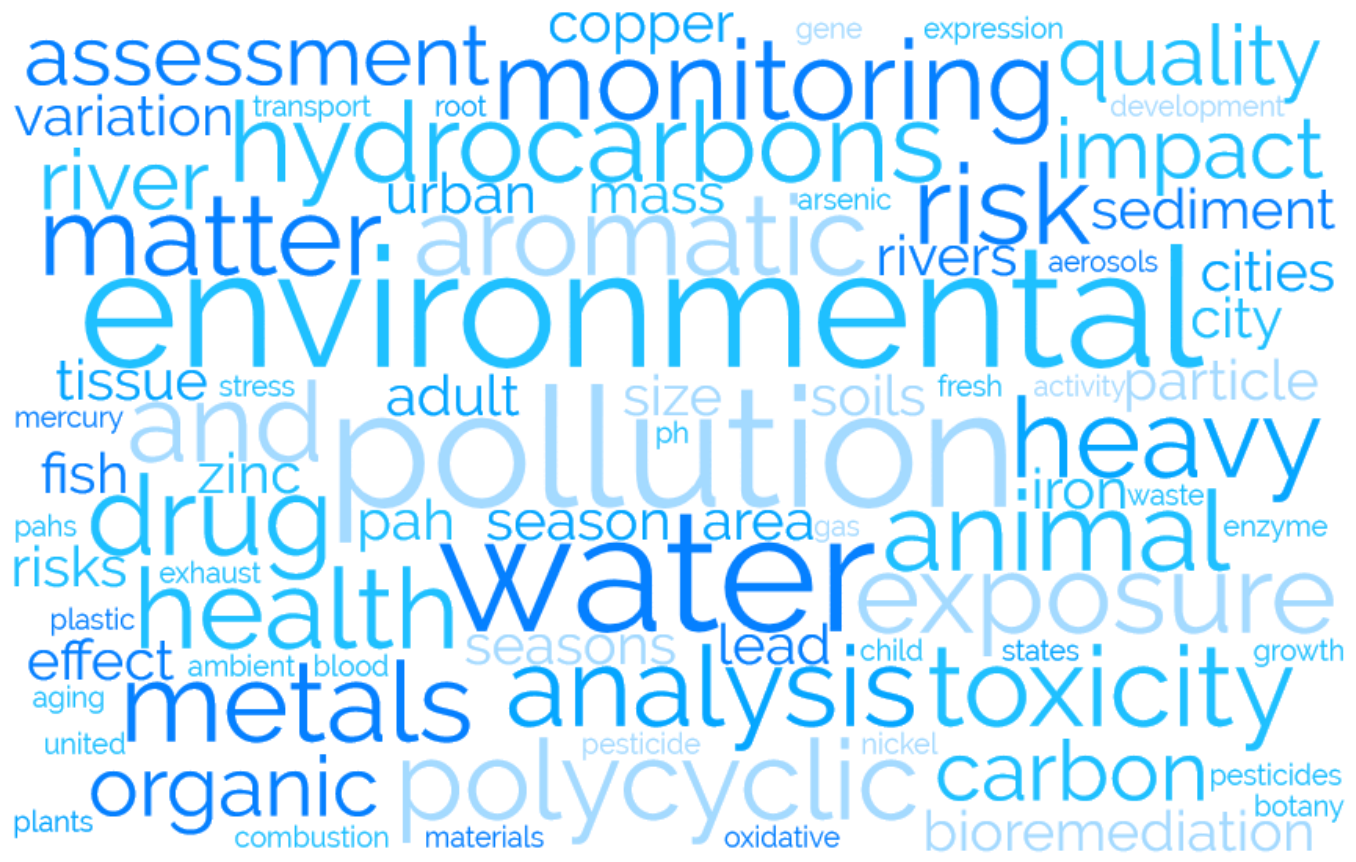

Figure 2 Word cloud of keywords used in Environmental Science and Pollution Research in 2018 (source from Scopus, data accessed on 03/06/2019). 
Many articles (see below) have been written, but a global guideline, dedicated simultaneously to teachers, researchers, reviewers and editorial board members working in environmental geochemistry, is missing. Therefore, we present the following critical views, based on our own experience, with a special emphasis on our main research field, i.e. environmental soil and water geochemistry.

\section{Material and analytical methods}

The robustness of research methods in environmental geochemistry studies is of major concern. Specific terminology is often not accurate, which raises questions about the methodology and instils doubt about the interpretation of results, as exemplified below.

Naming chemical compounds, whether organic or inorganic, is essential to success in chemistry. Some basic rules, established by the International Union of Pure and Applied Chemistry (IUPAC), should be followed when naming chemical compounds (Favre and Powell, 2014; Connely et al., 2005). The term 'heavy metals' should be avoided, as recently emphasised by Pourret and Bollinger (2018) and by Pourret (2018) and references therein (Figure 3). This should be replaced by 'trace elements/metals' or by 'potentially toxic elements/metals'. Although of wide use, the terms 'normality' or 'molarity', and their symbols $N$ and $M$, should preferably be avoided (NIST, 2004). Researchers should consider amount-of-substance concentration of the considered chemical element or species (more commonly called concentration), and its symbol $c$ with SI unit $\mathrm{mol} / \mathrm{m}^{3}$ (or a related acceptable unit) or molality of solute (symbol $m$ and SI unit $\mathrm{mol} / \mathrm{kg}$ ). 


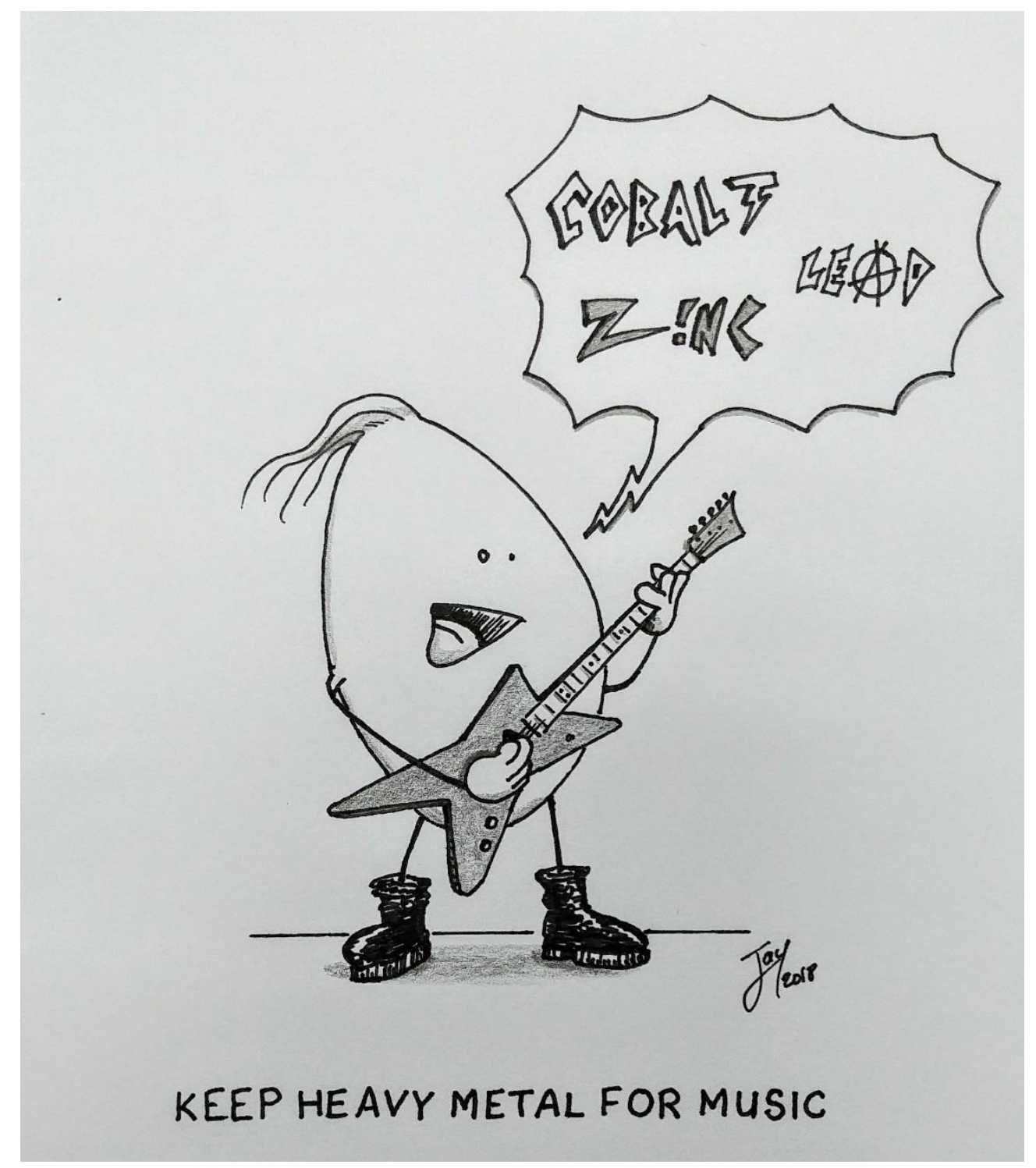

Figure 3 Cartoon illustrating the misused term "heavy metal" (artwork from Dr Justin Larrouzée).

Chemical fractionation is a concept often confused with speciation of elements, and mostly with speciation analysis and chemical species (see subsection 4). Indeed, chemical speciation must be distinguished from chemical fractionation, and a guideline may be found in Templeton et al. (2000). Chemical species may be categorised according to isotopic composition of the considered element, its oxidation and electronic states and its complex and 
molecular structure. Such description of the kind of chemical species has been recently discussed by Lespes et al. (2016).

When a paper is concerned with various steps within adsorption studies, we strongly suggest that authors refer to the recent critical review on this subject, written by Tran et al. (2017). Although we don't agree with all their comments, one can find here most of the issues we have encountered in several published papers.

The following points concerning adsorption data treatment should be considered:

(i) Thermodynamic calculations: Please remember that in thermodynamic equations you can only take the logarithm of the equilibrium constant as a dimensionless parameter.

(ii) Kinetics and/or isotherm models: Non-linear regression is more appropriate for obtaining parameters of kinetic models and isotherm models than linear regression (Limousin et al., 2007).

(iii) In the special case of metal studies, we would like to draw attention to another point: the $\mathrm{pH}$ changes will often lead to (partial) precipitation of insoluble metal (hydr)oxides, carbonates or phosphates, and this is also to be expected during separation of adsorbed metals by filtration or centrifugation (e.g. up to 93\% of (hydr)oxide form was filtered out even at low metal concentration; Haas et al., 2019).

Quality assurance and quality control (QA/QC) procedures for analytical data are often poorly described in many papers. Authors should, of course, add information about the number of replicated experiments (including preparation of the material, when this is the case) and analysis, and the corresponding standard deviation. Then, all numerical data (text and 
tables) should only display the correct number of significant digits (rounded value). However, the standard deviation (value \pm standard deviation), and, in all figures, the experimental data points, should contain their respective error bars. Moreover, there are several authoritative and detailed documents on various aspects of reference materials (RM), together with some internationally recognised definitions. Reference materials are an important tool for realising measurement quality and are used for method validation, calibration, uncertainty estimation, internal QC and external QA (i.e. proficiency testing) purposes (e.g. Quevauviller et al., 1997). Measurement validity can be assured when using:

(i) validated methods and appropriate equipment;

(ii) qualified and competent staff;

(iii) comparability with measurements made in other laboratories (traceability and measurement uncertainty);

(iv) independent evidence of performance (proficiency testing);

(v) well defined QC and QA procedures (third party accreditation is preferable).

Different types of RM are necessary for different functions. For instance, a certified $\mathrm{RM}$ is mandatory for method validation, whereas a working level RM is more appropriate for QC. More detailed guidance on the QA of chemical measurements, including cover of RM, calibration, QC and validation, is provided by the joint CITAC/Eurachem Guide (Barwick, 2016). Other advice is provided on using proper terminology in analytical geochemistry in papers by Sverdrup (1996), Potts (2012) and Wiedenbeck (2017).

We strongly recommend the provision of raw data in tabular form (as an appendix or on a repository). Indeed, an Open Data movement has recently taken off around the concept of 'FAIR' - where data is Findable, Accessible, Interoperable and Reusable (Wilkinson et al. 2016; 2018). These data can be used by those wishing to use modelling, and above all, it allows for greater transparency of the data used in the research (Piwowar, 2011). 
Environmental quality benchmarks, such as water quality guidelines, include indications for evaluating the possible damage from chemicals, physical and/or biological stressors: they are useful but not perfect tools (Chapman, 2018) as well as not always being adapted to the context of the studied case.

\section{Sample description}

When a specific study location is involved, authors should provide a readable map with precise coordinates in the correct format, as well as information on the geology of the area (type of rocks, and/or soil types). When providing this, it is essential to consider the recommendations of the International Union of Geological Sciences Subcommission on the Systematics of Igneous Rocks (Le Maitre et al., 2002) and the British Geological Survey's rock classification of sediments and sedimentary and metamorphic rocks (Hallsworth and Knox, 1999; Robertson, 1999). Also, the difference between natural and anthropogenic trace metals contents in soils needs to be properly reported in scientific publications for assessing soil contamination (Baize and Sterckeman, 2001; Desaules, 2012; Dung et al., 2013; Matschullat et al., 2000; Zhao et al. 2007).

Nearly forty years ago, Kretz (1983) proposed a systematised list of abbreviations for rock-forming minerals and mineral components. Its logical simplicity has led to wide recognition among authors and editors who were eager to accept an approved set of mineral symbols to save space in text, tables, and figures (e.g. Gth for goethite). This list was updated by Whitney and Evans (2010). If a native element occurs in nature, mineral abbreviations should not coincide with atomic symbols (e.g. Asp and not As for arsenopyrite, Cal and not Ca for calcite). 
Effective communication in the geosciences requires consistent use of stratigraphic nomenclature, especially divisions of geologic time. We recommend the use of the latest version of the International Chronostratigraphic Chart (Cohen et al., 2013) with the correct use of epoch, period, era, or eon, instead of a local name. Some further semantics can be found about the Anthropocene in Zalasiewicz et al. (2010; 2011). From a pedological point of view, a 'soil' is a complete ecosystem including living species; therefore, we strongly suggest using 'soil sample' and referring to the World Reference Base for Soil Resources (IUSS Working Group WRB, 2014). Some variations may exist between scientific communities, especially regarding weathering and regolith. Indeed, regolith science evolved from older disciplines, mainly geology and soil science, so 'younger' sciences rely on the terms from these disciplines, not always understanding them in detail or using them accurately (Eggleton, 2001).

\section{Ecological behaviour}

Unlike organic molecules, whose natural attenuation is a well-known process (Alexander, 2000), metallic elements, not undergoing microbial or chemical degradation, are persistent in the ecosystems of which they are often natural components. Several soil constituents, such as clays, Fe-, Al-, or Mn-(hydr)oxides, and organic matter, can bind or adsorb metals (Bradl, 2004). Therefore, the accumulation of metals in soils can generate ecological risks for plants and other organisms growing in them, and in turn, for human health through the food chain (Nagajyoti et al., 2010). It is, therefore, important to be able to analyse and understand the chemical behaviour and mobility of inorganic contaminants in polluted soils and how they lead to contamination of water bodies. It is also of interest to evaluate the feasibility of various remediation processes, for example with selective leaching reagents 
and/or with the use of metal-hyperaccumulating plants (Bhargava et al., 2012; Ali et al., 2013; Gaur et al., 2014; Ferraro et al., 2016; Lange et al., 2017). More information on hyperaccumulating plants may be found in Reeves et al. (2018), van der Ent et al. (2013) and Krämer (2010), although plants' status is presently somewhat unclear due to issues with contamination by soil particles (Faucon et al., 2007).

Among the important constituents of natural geochemical systems, organic matter (also known as humic substances), whether dissolved or not, is not a unique and pure chemical species (Aiken et al., 1985; Lehmann and Kleber, 2015; Myneni, 2019), but a mixture of molecules with various structures and molar mass, depending on their origin (animal and/or vegetal decomposition) (Piccolo, 2002; Sutton and Sposito, 2005). These organic compounds can react with light, chemicals or microbial species, and mainly bind metallic species (Lipczynska-Kochany, 2018).

For the evaluation of ecological risks, the determination of the total metal amount is not highly relevant, though it is necessary to determine metal speciation, which has been recognised for many years as the parameter against which to assess metal bioavailability in soils (Smolders et al., 2003; Crans, 2017). Definitions of bioavailability and bioaccessibility can be found in Semple et al. (2004), even if they are complicated to delineate. It gives information about the potential for the release and migration of contaminants and toxicity processes (Rüdel et al., 2015). Therefore, when performing risk assessment studies, it is necessary to determine both the bioavailability and the fractionation of metals in the different soil chemical phases (Nolan et al., 2003).

To further understand metal behavior (including mobility), many studies used selective and/or sequential extraction. Among the huge literature on that subject, the seminal 
paper by Tessier et al. (1979) or the BCR method (Ure et al., 1993) are often cited. However, such methods are very specific, and authors really need to justify the choice of their method (Ure, 1996; Figueiras et al., 2002; van der Ent et al., 2019). Indeed, if we consider the case of EDTA as extractant, the estimation of metal availability using the EDTA extraction methods are identified to be more appropriate for high metal concentrations (Peters, 1999), which is not applicable for every environmental sample. For instance, only a small range of single chemical extractants (e.g., EDTA, $\mathrm{CaCl}_{2}$ ) have been used to relate plant cobalt (Co) uptake with an operationally defined available concentration of extracted Co (Collins and Kinsela, 2011). Moreover, acetic acid-EDTA extractable fraction is an enhanced predictor of Co bioavailability in contaminated soils (Faucon et al., 2009). EDTA is often considered to extract primarily organically-bound trace elements from soil and not only elements nonspecifically adsorbed on the exchange complex (Albanese, 2008; Rupa and Shukla, 1999). Eventually, extraction should be compared with modelling (e.g. Cui and Weng, 2015; Pourret et al., 2015) or with other techniques such as DGT (diffusive gradients in thin-films technique) to be validated (e.g. Bravin et al., 2010).

Moreover, these studies are generally carried out on artificially contaminated soils (e.g. Zapusek and Lestan, 2009; Lange et al., 2016): both the nature and the amount of metallic element(s) can be simultaneously controlled. The effects of added metal elements are commonly studied just after the contamination. However, metallic element sorption in soils evolves during long periods of time ranging from days to decades (Ma et al., 2006). During this process, named 'ageing' or 'aging', the speciation, the bioavailability and the fractionation of metals, change. Consequently, the results, based on soil samples freshly spiked with metallic solutions, and assessing ecotoxic effects, may not be relevant 
(Alexander, 2000; Renella et al., 2002; Davies et al., 2003). This represents a serious drawback for risk assessment studies related to older contaminated sites.

When lawyers working for (inter)national regulating agencies define concentration limits for potentially toxic substances (Antoniadis et al., 2019), they are balancing between risks and profits for environmental protection, including human health, and the 'best available technologies not entailing excessive cost' (a.k.a. 'BATNEEC'). Furthermore, as proposed by Chapman (2002), in order to avoid all these drawbacks, authors should compare bioaccumulation testing with toxicity testing.

\section{Ecological risk assessment}

For risk assessment studies, environmental toxicology is often considered, e.g. singlespecies testing for screening purposes. However, ecotoxicology is more relevant than ecological toxicology in tests, test species and exposures (Bost and Sanchez, 2018; de Souza Machado et al., 2019; Hitchcock et al., 2018). It is, therefore, required for predicting real effects and for site-specific assessments, e.g. use of biomarkers (Forbes et al., 2006), or of microbial toxicology (Ghiglione et al., 2016). During the last thirty years, ecotoxicology and ecology have shown similar developmental trends; such as closer cooperation between those disciplines, which has benefited them both (Chapman, 2002; Bradbury et al., 2004; Rohr et al., 2016). Ecology can be integrated into toxicology: either distinctly, by providing information on pre-selected test species; or as part of test species choice; the latter being preferable. General guidelines for serious and chronic testing, and criteria for species choice, differ between environmental toxicology and ecotoxicology. An overall framework has been proposed by Chapman (2002), based on ecological risk assessment, for combining ecology and toxicology for decision-making. Moreover, the pros and cons of ecological risk 
assessment based on data from different levels of biological organisation are reviewed by Rohr et al. (2016).

The terms 'dose-response' or 'dose-effect' are often used to describe the causal links between biological effects and exposure. This use of the term 'dose' in aquatic toxicology comes from mammalian toxicology (Nikinmaa and Schlenk, 2010; Duffus, 2003; Chapman, 2002). Indeed, when a compound is delivered to an animal, the term 'dose' designates the amount of this compound entering the animal. A lethal dose (often designated as LD50) is also used to describe the dose of a compound that kills $50 \%$ of the exposed population. Importantly, when animals are treated through inhalation, the term is modified to 'concentration' that affects $50 \%$ of the population. This distinction is because when animals are exposed to air, the dose is not known, only the total concentration in the air is measured. A comparable situation occurs for aquatic organisms: whenever an organism is exposed to a compound in water, only the total concentration of this compound in water is known. Thus, the main difference between 'dose' and 'concentration' is that the 'dose' of a compound is rarely known in an aquatic organism even if the chemical compound is measured within the organism. This uncertainty is primarily due to whether the compound is bioavailable to a specific molecular target within the organism. Therefore, it is imperative to use the proper terminology 'concentration-response' or 'concentration-dependent' when dealing with aquatic organisms (Nikinmaa and Schlenk, 2010).

As highlighted by Hooton (1987), a major difference exists between 'toxin' and 'toxicant'. This distinction is that: (i) a 'toxin' is a poisonous substance produced by a biological organism such as a microbe, animal or plant (Duffus, 2003); (ii) a 'toxicant' is a compound that is not naturally occurring and its entry into the environment is of human origin. Moreover, metals do not originate from biological sources, they are thus considered toxicants. The term 'xenobiotic' should be used when a doubt exists; it includes both toxin 
and toxicant if the compound is not naturally occurring to the environment (Nikinmaa and Schlenk, 2010).

\section{Geochemical modelling}

As reviewed by Nordstrom (2012), modelling has become so prevalent that many researchers cannot imagine publishing results without using models. However, the use of computer codes to execute calculations has led to a distinction between code and model. This type of controversy regarding model validation has brought into question what we mean by a 'model' and by 'validation' (Bair, 1994). The common significance of validation may be common in engineering practice and seems useful in legal practice. It is, however, divergent to scientific practice. It brings into question our understanding of science and how it can best be applied to environmental studies (Nordstrom, 2012).

Moreover, most studies using models are based on laboratory experiments with very simplified systems, such as a metal nitrate salt in pure water. But real-world systems are, of course, more complicated. To add value to such work, the authors should firstly study the competition and influence of some other anions and cations, and then they should thoroughly test some real samples containing their target species. Moreover, in studies about metal species, detailed speciation modelling (ECOSAT, MINFIT, MINTEQ, PHREEQC, WHAM, ...) is required in order to have a better insight into the behaviour of such systems. The abovementioned are chemical equilibrium models used to predict metal speciation and metal bioavailability in environmental systems. Special attention must be paid to the choice of equilibrium constants (Hummel et al., 2019). However, users should bear in mind that environmental systems are always dynamic and rarely at equilibrium, even if some reactions 
are relatively fast (e.g. metal complexation to organic or inorganic ligands in water (Di Bonito et al., 2018)); in this case, the implementation of the so-called 'Biotic Ligand Model (BLM)' can be useful (Rüdel et al., 2015). When sediments are considered, a combination of several tests and criteria should also be assessed (Alves et al., 2018).

We are often concerned with the nature of salt (commonly seen as a neutral electrolyte) selected for the required ionic strength to be set, or in case of artificial contamination. Yet, how should one select the appropriate anion? From a chemist's point of view, nitrate salts are probably the best choice, because they are always readily soluble, and they rarely form complexes, although soluble and with low stability constants (Štuliková, 1991). But of course, nitrate ion has nutritional properties for plants and some biological effects for soil micro-organisms (Jacoby et al., 2017). Sodium nitrate is thus a better choice for ionic strength setting, but calcium chloride is normally selected when dealing with soil solution representativeness (Komarek et al., 2007). In this case, Ca(II) can favour the formation precipitated compounds with carbonate or phosphate species, and that chloride ions can form (in)soluble complexes with many metal cations such as $\mathrm{Cu}$ (II) or $\mathrm{Pb}$ (II).

\section{Concluding remarks}

Of course, we understand that several points in this position paper are already frequently published in many respected environmental science journals. In an extensive compilation of the top-cited articles published in environmental science journals, Khan and Ho (2012) analysed the papers published in 181 journals during the $1899-2010$ period with regard to institution and country of origin, but they were also discussed according to their life span. They have found that between 1971 and 2002, 88 top-cited articles in environmental 
science were published, each with more than 500 total citations. Even though some of those often-cited articles are specifically on geochemistry, it should not mean that misunderstood scientific facts continue to be incorrectly repeated by researchers.

This Trend Editorial was intended to be constructive, not polemic. We sincerely hope that it will allow our colleagues as authors to avoid making mistakes or replicating misconceptions in their submitted papers. Moreover, we believe our thoughts can also be useful to editorial board members and reviewers of many environmental geochemistry journals.

\section{Acknowledgments}

We are grateful to Dr Justin Larrouzée for drawing the original artwork in Figure 3.

\section{Disclosure statement}

No potential conflict of interest was reported by the authors.

\section{Funding}

This research did not receive any specific grant from funding agencies in the public, commercial or non-profit sectors.

\section{References}


Aiken, G.R., McKnight, D.M., Wershaw, R.L. and MacCarthy, P. (1985) Humic substances in soil, sediment and water: geochemistry, isolation and characterization. Wiley Intersciences, New York.

Albanese, S. (2008) Evaluation of the bioavailability of potentially harmful elements in urban soils through ammonium acetate-EDTA extraction: a case study in southern Italy. Geochemistry: Exploration, Environment, Analysis 8, 49-57.

Alexander, M. (2000) Aging, Bioavailability, and Overestimation of Risk from Environmental Pollutants. Environmental Science and Technology 34, 4259-4265.

Ali, H. and Khan, E. (2017) Environmental chemistry in the twenty-first century. Environmental Chemistry Letters 15, 329-346.

Ali, H., Khan, E. and Sajad, M.A. (2013) Phytoremediation of heavy metals-Concepts and applications. Chemosphere 91, 869-881.

Alves, C.M., Ferreira, C.M.H. and Soares, H.M.V.M. (2018) Relation between different metal pollution criteria in sediments and its contribution on assessing toxicity. Chemosphere 208, 390-398.

Amundson, R., Richter, D.D., Humphreys, G.S., Jobbágy, E.G. and Gaillardet, J. (2007) Coupling between biota and earth materials in the critical zone. Elements 3, 327-332.

Antoniadis, V., Shaheen, S.M., Levizou, E., Shahid, M., Niazi, N.K., Vithanage, M., Ok, Y.S., Bolan, N., Rinklebe, J. (2019) A critical prospective analysis of the potential toxicity of trace element regulation limits in soils worldwide: Are they protective concerning health risk assessment? - A review. Environment International, 127: 819-847.

Bair, E.S. (1994) Model (in)validation - a view from the courtroom. Groundwater 32, 530531. 
Baize, D. and Sterckeman, T. (2001) Of the necessity of knowledge of the natural pedogeochemical background content in the evaluation of the contamination of soils by trace elements. Science of the Total Environment. 264, 127-139.

Balmford, A. (2013) Pollution, Politics, and Vultures. Science 339, 653-654.

Barwick V. (2016) Eurachem/CITAC Guide: Guide to Quality in Analytical Chemistry: An Aid to Accreditation ( $3^{\text {rd }}$ ed.). ISBN 978-0-948926-32-7. Available from www.eurachem.org.

Bhargava, A., Carmona, F.F., Bhargava, M. and Srivastava, S. (2012) Approaches for enhanced phytoextraction of heavy metals. Journal of Environmental Management 105, 103-120.

Bost, M. \& Sanchez, W. (2018) Ecotoxicology and toxicology: problems and decisions (Editorial). Environmental Science and Pollution Research 25, 2005-2006.

Botkin, D.B., and Keller E.A. (2014) Environmental Science: Earth as a Living Planet, 9th Edition. Wiley.

Bradbury, S.P., Feijtel, T.C.J. and Leeuwen, C.J.V. (2004) Peer Reviewed: Meeting the Scientific Needs of Ecological Risk Assessment in a Regulatory Context. Environmental Science \& Technology 38, 463A-470A.

Bradl, H.B. (2004) Adsorption of heavy metal ions on soils and soils constituents. Journal of Colloid and Interface Science 277, 1-18.

Brantley, S.L., Goldhaber, M.B. and Ragnarsdottir, K.V. (2007) Crossing disciplines and scales to understand the critical zone. Elements 3, 307-314.

Bravin, M.N., Michaud, A.M., Larabi, B. and Hinsinger, P. (2010) RHIZOtest: A plant-based biotest to account for rhizosphere processes when assessing copper bioavailability. Environmental Pollution 158, 3330-3337. 
Briggs, W.M., Soon, W., Legates, D. and Carter, R.M. (2011) A vaccine against arrogance. Water Air and Soil Pollution 220, 5-6.

Carroll, C., Hartl, B., Goldman, G.T., Rohlf, D.J., Treves, A., Kerr, J.T., Ritchie, E.G., Kingsford, R.T., Gibbs, K.E., Maron, M. and Watson, J.E.M. (2017) Defending the scientific integrity of conservation-policy processes. Conservation Biology 31, 967-975.

Casadevall, A., Fang, F.C. (2016) Rigorous Science: a How-To Guide. mBio, 7(6): e0190216.

Chapman, P.M. (2002) Mistakes made/lessons learned. Environmental Toxicology and Chemistry 21, 891-893.

Chapman, P.M. (2018) Environmental quality benchmarks - the good, the bad, and the ugly. Environmental Science and Pollution Research 25, 3043-3046.

Chawla, D.S. (2019) Elsevier probes dodgy citations. Nature 73, 174.

Chorover, J., Kretzschmar, R., Garcia-Pichel, F. and Sparks, D.L. (2007) Soil biogeochemical processes within the critical zone. Elements 3, 321-326.

Cohen, K.M., Finney, S.C., Gibbard, P.L. and Fan, J.-X. (2013) The ICS International Chronostratigraphic Chart. Episodes 35, 199-204.

Collins, R.N. and Kinsela, A.S. (2011) Pedogenic factors and measurements of the plant uptake of cobalt. Plant and Soil 339, 499-512.

Connelly, N.G., Damhus, T., Hartshorn, R.M. and Hutton, A.T. (2005) Nomenclature of inorganic chemistry - IUPAC recommendations 2005. RSC Publishing.

Crans, D.C. (2017) Preface: Applications of speciation chemistry in a modern society. Coordination Chemistry Reviews352, 398-400.

Cui, Y. and Weng, L. (2015) Interpretation of heavy metal speciation in sequential extraction using geochemical modelling. Environmental Chemistry 12, 163-173. 
Davies, N.A., Hodson, M.E. and Black, S. (2003) The influence of time on lead toxicity and bioaccumulation determined by the OECD earthworm toxicity test. Environmental Pollution 121, 55-61.

de Souza Machado, A.A., Wood, C.M. and Werner Kloas, W. (2019) Novel concepts for novel entities: Updating ecotoxicology for a sustainable Anthropocene (Viewpoint). Environmental Science and Technology 53, 4680-4682.

Desaules, A. (2012) Critical evaluation of soil contamination assessment methods for trace metals. Science of the Total Environment 426, 120-131.

Di Bonito, M., Lofts, S. and Groenenberg, J.E. (2018) Chapter 11 - Models of Geochemical Speciation: Structure and Applications A2 - Vivo, Benedetto De. In: Belkin, H.E., Lima, A. (Eds.), Environmental Geochemistry (Second Edition). Elsevier, pp. 237-305.

Duffus, J.H. (2003) Toxicology of Metals-Science Confused by Poor Use of Terminology. Archives of Environmental Health: An International Journal 58, 263-266.

Dung, T.T.T., Cappuyns, V., Swennen, R. and Phung, N.K. (2013) From geochemical background determination to pollution assessment of heavy metals in sediments and soils. Reviews in Environmental Science and Bio/Technology 12, 335-353.

Eggleton, R. (2001) The regolith glossary. Surficial geology, soils and landscapes. CRCLEME.

Faucon, M.P., Colinet, G., Mahy, G., Ngongo Luhembwe, M., Verbruggen, N. and Meerts, P. (2009) Soil influence on $\mathrm{Cu}$ and Co uptake and plant size in the cuprophytes Crepidorhopalon perennis and C. tenuis (Scrophulariaceae) in SC Africa. Plant Soil 317, 201-212.

Favre, H.A., Powell, W.H. (2014) Nomenclature of Organic Chemistry: IUPAC Recommendations and Preferred Names 2013, RSC. 
Ferraro, A., Fabbricino, M., van Hullebusch, E.D., Esposito, G. and Pirozzi, F. (2016) Effect of soil/contamination characteristics and process operational conditions on aminopolycarboxylates enhanced soil washing for heavy metals removal: a review. Reviews in Environmental Science and Bio/Technology, 15(1): 111-145.

Field, J.P., Breshears, D.D., Law, D.J., Villegas, J.C., López-Hoffman, L., Brooks, P.D., Chorover, J., Barron-Gafford, G.A., Gallery, R.E., Litvak, M.E., Lybrand, R.A., McIntosh, J.C., Meixner, T., Niu, G.-Y., Papuga, S.A., Pelletier, J.D., Rasmussen, C.R. and Troch, P.A. (2015) Critical Zone Services: Expanding Context, Constraints, and Currency beyond Ecosystem Services. Vadose Zone Journal 14, 1.

Filella, M. (2014) Environmental chemistry: a discipline standing on two shoulders. Environmental Chemistry 11, 37-40.

Filgueiras, A.V., Lavilla, I. and Bendicho, C. (2002) Chemical sequential extraction for metal partitioning in environmental solid samples. Journal of Environmental Monitoring, 4(6): 823-857.

Fong, E.A. and Wilhite, A.W. (2017) Authorship and citation manipulation in academic research. PLoS ONE 12, e0187394.

Forbes, V.E., Palmqvist, A. and Bach, L. (2006) The use and misuse of biomarkers in ecotoxicology. Environmental Toxicology and Chemistry 25, 272-280.

Garfield, E. (1980) From citation amnesia to bibliographic plagiarism. Current Contents \#23, $5-9$.

Gaur, N., Flora, G., Yadav, M. and Tiwari, A. (2014) A review with recent advancements on bioremediation-based abolition of heavy metals. Environmental Science: Processes \& Impacts 16, 180-193. 
Ghiglione, J.-F., Martin-Laurent, F. and Pesce, S. (2016) Microbial ecotoxicology: an emerging discipline facing contemporary environmental threats (Editorial). Environmental Science and Pollution Research 23, 3981-3983.

Goldman, G.T., Berman, E., Halpern, M., Johnson, C., Kothari, Y., Reed, G. and Rosenberg, A.A. (2017) Ensuring scientific integrity in the Age of Trump. Science 355, 696-698.

Haas S., Boschi V., Grannas A. (2019) Metal sorption studies biased by filtration of insoluble metal oxides and hydroxides. Science of the Total Environment 646, 1433-1439.

Hallsworth, C.R. and Knox, R. (1999) BGS rock classification scheme. Volume 3, classification of sediments and sedimentary rocks. British Geological Survey.

Hitchcock, D.J., Andersen, T. Varpe, Ø. and Borgå, K. (2018) Improving data reporting in ecotoxicological studies (Viewpoint). Environmental Science and Technology 52, 80618062.

Hofseth, L.J. (2018) Getting rigorous with scientific rigor. Carcinogenesis, 39(1): 21-25.

Hooton, K.A. (1987) Words, words (Letter). Environmental Science and Technology 21, 1028

Hummel W., Filella M. and Rowland D. (2019) Review: Where to find equilibrium constants? Science of the Total Environment 692, 49-59.

IUSS Working Group WRB (2014) World reference base for soil resources, World Soil Resources Reports 106. FAO, Rome.

Jacoby, R., Peukert, M., Succurro, A., Koprivova, A. and Kopriva, S. (2017) The Role of Soil Microorganisms in Plant Mineral Nutrition-Current Knowledge and Future Directions. Frontiers in Plant Science 8.

Khan, M.A. and Ho, Y.-S. (2012) Top-cited articles in environmental sciences: Merits and demerits of citation analysis. Science of the Total Environment 431, 122-127.

Koch, W. (2016) Ethics and chemistry: the role of learned societies, as exemplified by the German chemical societies. Toxicological \& Environmental Chemistry 98, 1060-1066. 
Komárek, M., Tlustoš, P., Száková, J. and Chrastný, V. (2007) The Role of Chloride Salts in Chemically Enhanced Phytoextraction of Heavy Metals From a Contaminated Agricultural Soil. Bulletin of Environmental Contamination and Toxicology 78, 176-180.

Krämer, U. (2010) Metal hyperaccumulation in plants. Annual Review of Plant Biology 61, $517-534$.

Kretz, R. (1983) Symbols for rock-forming minerals, American Mineralogist, 68, 277-279.

Lange, B., Pourret, O., Meerts, P., Jitaru, P., Cancès, B., Grison, C. and Faucon, M.-P. (2016) Copper and cobalt mobility in soil and accumulation in a metallophyte as influenced by experimental manipulation of soil chemical factors. Chemosphere 146, 75-84

Lange, B., van der Ent, A., Baker, A.J.M., Echevarria, G., Mahy, G., Malaisse, F., Meerts, P., Pourret, O., Verbruggen, N. and Faucon, M.-P. (2017) Copper and cobalt accumulation in plants: a critical assessment of the current state of knowledge. New Phytologist 213, 537 551.

Le Maitre R.W., Streckeisen A. and Zanettin B. (2002) Igneous rocks: IUGS classification and glossary : recommendations of the International Union of Geological Sciences, Subcommission on the Systematics of Igneous Rocks. Cambridge University Press.

Lehmann, J. and Kleber, M. (2015) The contentious nature of soil organic matter. Nature 528, 60.

Lespes, G., Zuliani, T. and Schaumlöffel, D. (2016) Need for revisiting the terminology about speciation. Environmental Science and Pollution Research 23, 15767-15770.

Lichtfouse, E., Schwarzbauer, J. and Robert, D. (2012) Social chemistry. Environmental Chemistry Letters 10, 1-4.

Limousin, G., Gaudet, J.P., Charlet, L., Szenknect, S., Barthès, V. and Krimissa, M. (2007) Sorption isotherms: A review on physical bases, modeling and measurement. Applied Geochemistry 22, 249-275. 
Lipczynska-Kochany, E. (2018) Effect of climate change on humic substances and associated impacts on the quality of surface water and groundwater: A review. Science of the Total Environment, 640-641, 1548-1565.

Ma, Y., Lombi, E., Oliver, I.W., Nolan, A.L. and McLaughlin, M.J. (2006) Long-Term Aging of Copper Added to Soils. Environmental Science and Technology 40, 6310-6317.

Matschullat, J., Ottenstein, R. and Reimann, C. (2000) Geochemical background - can we calculate it? Environmental Geology 39, 990-1000.

McNutt, M.K., Bradford, M., Drazen, J.M., Hanson, B., Howard, B., Hall Jamieson, K., Kiermer, V., Marcus, E., Kline Pope, B., Schekman, R., Swaminathan, S., Stang, P.J. and Verma, I.M. (2018) Transparency in authors' contributions and responsibilities to promote integrity in scientific publication. Proceedings of the National Academy of Sciences of the United States of America 115, 2557-2560.

Myneni, S. C. B. (2019) Chemistry of Natural Organic Matter-The Next Step: Commentary on a Humic Substances Debate. Journal of Environmental Quality 48, 233-235.

Nagajyoti, P.C., Lee, K.D. and Sreekanth, T.V.M. (2010) Heavy metals, occurrence and toxicity for plants: a review. Environmental Chemistry Letters 8, 199-216.

Nikinmaa, M. and Schlenk, D. (2010) Uses of phrases. Aquatic Toxicology 97, 1-2.

NIST (2004) SI Unit rules and style conventions. https://physics.nist.gov/cuu/Units/checklist.html

Nolan, A.L., Lombi, E. and McLaughlin, M.J. (2003) Metal Bioaccumulation and Toxicity in Soils; Why Bother with Speciation? Australian Journal of Chemistry 56, 77-91.

Nordstrom, K.D. (2012) Models, validation, and applied geochemistry: Issues in science, communication, and philosophy. Applied Geochemistry 27, 1899-1919.

Peters, R.W. (1999) Chelant extraction of heavy metals from contaminated soils. J. Hazard. Mater. 66, 151-210. 
Petersen, A.M., Pan, R.K., Pammolli, F. and Fortunato, S. (2019) Methods to account for citation inflation in research evaluation. Research Policy 48, 1855-1865.

Piccolo, A. (2002) The supramolecular structure of humic substances: A novel understanding of humus chemistry and implications in soil science, Advances in Agronomy. Academic Press, pp. 57-134.

Piwowar, H.A. (2011) Who Shares? Who Doesn't? Factors Associated with Openly Archiving Raw Research Data. PLOS ONE 6, e18657.

Potts, P.J. (2012) Glossary of Analytical and Metrological Terms from the International Vocabulary of Metrology (2008). Geostandards and Geoanalytical Research 36, 231-246. Pourret O. (2018) On the Necessity of Banning the Term "Heavy Metal" from the Scientific Literature. Sustainability 10, 2879.

Pourret, O. and Bollinger, J.-C. (2018) "Heavy metal" - What to do now: To use or not to use? Science of the Total Environment 610, 419-420.

Pourret, O., Lange, B., Houben, D., Colinet, G., Shutcha, M. and Faucon, M.P. (2015) Modeling of cobalt and copper speciation in metalliferous soils from Katanga (Democratic Republic of Congo). Journal of Geochemical Exploration 149, 87-96.

Quevauviller, P., Rauret, G., López-Sánchez, J.F., Rubio, R., Ure, A. and Muntau, H. (1997) Certification of trace metal extractable contents in a sediment reference material (CRM 601) following a three-step sequential extraction procedure. Science of the Total Environment 205, 223-234.

Record, N.R. (2017) A People's Science. Limnology and Oceanography Bulletin 26, 36-37.

Reeves, R.D., Baker, A.J.M., Jaffré, T., Erskine, P.D., Echevarria, G. and van der Ent, A. (2018) A global database for plants that hyperaccumulate metal and metalloid trace elements. New Phytologist, 218, 407-411. 
Renella, G., Chaudri, A.M. and Brookes, P.C. (2002) Fresh additions of heavy metals do not model long-term effects on microbial biomass and activity. Soil Biology and Biochemistry 34, 121-124.

Robertson, S.J. (1999) BGS rock classification scheme. Volume 2, classification of metamorphic rocks. British Geological Survey.

Rohr, J.R., Salice, C.J. and Nisbet, R.M. (2016) The pros and cons of ecological risk assessment based on data from different levels of biological organization. Critical Reviews in Toxicology 46, 756-784.

Rüdel, H., Díaz Muñiz, C., Garelick, H., Kandile, N.G., Miller, B.W., Pantoja Munoz, L., Peijnenburg, W.J.G.M., Purchase, D., Shevah, Y., van Sprang, P., Vijver, M. and Vink, J.P.M. (2015) Consideration of the bioavailability of metal/metalloid species in freshwaters: Experiences regarding the implementation of biotic ligand model-based approaches in risk assessment frameworks. Environmental Science and Pollution Research 22, 7405-742.

Rupa, T.R. and Shukla, L.M. (1999) Comparison of four extractants and chemical fractions for assessing available zinc and copper in soils of India. Communications in Soil Science and Plant Analysis 30, 2579-2591.

Sawyer, F.G. (1979) An overview: Impact of environmental regulations. Water Air and Soil Pollution 12, 37-45.

Sedlak, D. (2016) A Picture Worth 250 Million Words (and Counting). Environmental Science and Technology 50, 2745-2746.

Semple, K.T., Doick, K.J., Jones, K.C., Burauel, P., Craven, A., Harms, H. (2004) Defining Bioavailability and Bioaccessibility of Contaminated Soil and Sediment is Complicated. Environmental Science \& Technology, 38(12): 228A-231A. 
Smith, E., Williams-Jones, B., Master, Z., Larivière, V., Sugimoto, C.R., Paul-Hus, A., Shi, M. and Resnik, D.B. (2019) Misconduct and misbehavior related to authorship disagreements in collaborative science. Science and Engineering Ethics (in the press).

Smolders, E., McGrath, S.P., Lombi, E., Karman, C.C., Bernhard, R., Cools, D., Van den Brande, K., van Os, B. and Walrave, N. (2003) Comparison of toxicity of zinc for soil microbial processes between laboratory-contaminated and polluted field soils. Environmental Toxicology and Chemistry 22, 2592-2598.

Štulíková, M. (1991) Is nitrate really an inert electrolyte?: A brief review. Talanta 38, 805807.

Stumm, W., Schwarzenbach, R. and Sigg, L. (1983) From Environmental Analytical Chemistry to Ecotoxicology_A Plea for More Concepts and Less Monitoring and Testing. Angewandte Chemie International Edition in English 22, 380-389.

Sutton, R. and Sposito, G. (2005) Molecular Structure in Soil Humic Substances: The New View. Environmental Science and Technology 39, 9009-9015.

Sverdrup, H. (1996) Geochemistry, the key to understanding environmental chemistry. Science of the Total Environment 183, 67-87.

Sweedler, J.V. (2019) The evolving world of scientific publications: From unethical behaviors to new mandates from funding agencies (Editorial). Analytical Chemistry 91, 1673-1674. Templeton, D.M., Ariese, F., Cornelis, R., Danielsson, L.-G., Muntau, H., Van Leeuwen, H.P. and Lobinski, R. (2000) Guidelines for terms related to chemical speciation and fractionation of elements. Definitions, structural aspects, and methodological approaches. Pure and Applied Chemistry 72, 1453-1470.

Tessier, A., Campbell, P.G.C. and Bisson, M. (1979) Sequential extraction procedure for the speciation of particulate trace metals. Analytical Chemistry 51, 844-851. 
Tran, H.N., You, S.-J., Hosseini-Bandegharaei, A. and Chao, H.-P. (2017) Mistakes and inconsistencies regarding adsorption of contaminants from aqueous solutions: A critical review. Water Research 120, 88-116.

Trevors, J.T. and Saier, M.H., Jr (2011) A vaccine against ignorance? Water Air and Soil Pollution 220, 1-3.

Trevors, J.T. and Saier, M.H., Jr. (2008) Corruption and fraud in science (Editorial). Water Air and Soil Pollution 189, 1-3.

Ure, A.M. (1996) Single extraction schemes for soil analysis and related applications. Science of the Total Environment 178, 3-10.

Ure, A.M., Quevauviller, P., Muntau, H. and Griepink, B. (1993) Speciation of Heavy Metals in Soils and Sediments. An Account of the Improvement and Harmonization of Extraction Techniques Undertaken Under the Auspices of the BCR of the Commission of the European Communities. International Journal of Environmental Analytical Chemistry 51, 135-151.

van der Ent, A., Baker, A.J.M., Reeves, R.D., Pollard, A.J. and Schat, H. (2013) Hyperaccumulators of metal and metalloid trace elements: Facts and fiction. Plant Soil $362,319-334$.

van der Ent, A., Nkrumah, P.N., Tibbett, M. and Echevarria, G. (2019) Evaluating soil extraction methods for chemical characterization of ultramafic soils in Kinabalu Park (Malaysia). Journal of Geochemical Exploration 196, 235-246.

Voulvoulis, N. and \& Burgman, M.A. (2019) The contrasting roles of science and technology in environmental challenges. Critical Reviews in Environmental Science and Technology 49, 1079-1106.

Whitney, D.L. and Evans, B.W. (2010) Abbreviations for names of rock-forming minerals. American Mineralogist 95, 185-187. 
Wiedenbeck, M., (2017) Proper Terminology in Analytical Geochemistry. Elements, 13(6): 446.

Wilhite, A., Fong, E.A. and Wilhite, S. (2019) The influence of editorial decisions and the academic network on self-citations and journal impact factors. Research Policy 48, 15131522.

Wilkinson, M.D., Dumontier, M., Aalbersberg, I.J., Appleton, G., Axton, M., Baak, A., Blomberg, N., Boiten, J.-W., da Silva Santos, L.B., Bourne, P.E., Bouwman, J., Brookes, A.J., Clark, T., Crosas, M., Dillo, I., Dumon, O., Edmunds, S., Evelo, C.T., Finkers, R., Gonzalez-Beltran, A., Gray, A.J.G., Groth, P., Goble, C., Grethe, J.S., Heringa, J., 't Hoen, P.A.C., Hooft, R., Kuhn, T., Kok, R., Kok, J., Lusher, S.J., Martone, M.E., Mons, A., Packer, A.L., Persson, B., Rocca-Serra, P., Roos, M., van Schaik, R., Sansone, S.-A., Schultes, E., Sengstag, T., Slater, T., Strawn, G., Swertz, M.A., Thompson, M., van der Lei, J., van Mulligen, E., Velterop, J., Waagmeester, A., Wittenburg, P., Wolstencroft, K., Zhao, J., Mons, B. (2016) The FAIR Guiding Principles for scientific data management and stewardship. Scientific Data, 3: 160018.

Wilkinson, M.D., Sansone, S.-A., Schultes, E., Doorn, P., Bonino da Silva Santos, L.O., Dumontier, M. (2018) A design framework and exemplar metrics for FAIRness. Scientific Data, 5: 180118.

Zalasiewicz, J., Williams, M., Haywood, A. and Ellis, M. (2011) The Anthropocene: a new epoch of geological time? Philosophical Transactions of the Royal Society A: Mathematical, Physical and Engineering Sciences 369, 835-841.

Zalasiewicz, J., Williams, M., Steffen, W. and Crutzen, P. (2010) The New World of the Anthropocene. Environmental Science and Technology 44, 2228-2231.

Zapusek, U. and Lestan, D. (2009) Fractionation, mobility and bio-accessibility of Cu, Zn, $\mathrm{Cd}, \mathrm{Pb}$ and $\mathrm{Ni}$ in aged artificial soil mixtures. Geoderma 154, 164-169. 
Zhao, F.J., McGrath, S.P. and Merrington, G. (2007) Estimates of ambient background concentrations of trace metals in soils for risk assessment. Environmental Pollution 148, 221-229.

Zoller, U. (2000) Environmental chemistry: The disciplinary/correction transdisciplinary/prevention paradigm shift (Editorial). Environmental Science and Pollution Research 7, 63-65. 